FAKULTAS ILMU KOMPUTER

YULI YANAH

TUGAS 1 - SISTEM INFORMASI MANAJEMEN

TUGAS SISTEM INFORMASI MANAJEMEN

(Study Tentang Manfaat System Informasi, Pengaruh Sistem Informasi Bagi Perusahaan, Data \& Informasi, dan Profesi Dibidang Sistem Informasi)

\author{
Yuli Yanah
}

$1711059012 p$

Fakultas Ilmu Komputer

Jurusan Sistem Informasi

Institute Informasi and Business Darmajaya

Yanayuli.1711059012P@mail.darmajaya.ac.id

\begin{abstract}
Setiap organisasi maupun perusahaan sekarang ini sering menggunakan Sistem Informasi Manajemen karena dengan adanya system informasi manajemen dapat membantu suatu organisasi atau perusahaan dalam pengambilan keputusan agar sesuai dengan tujuan yang di ingikan oleh perusahaan atau organisasi tersebut.Sistem Informasi Manajemen mempunyai peranan penting bagi perusahaan atau organisasi adalah suatu sistem perencanaan di dalam perusahaan yang melibatkan pengendalian internal seperti pemanfaatan sumber daya, dokumen, teknologi, dan akuntansi manajemen sebagai salah satu strategi dalam bisnis. Pada intinya, sistem informasi manajemen dalam bisnis atau perusahaan bertujuan untuk mengumpulkan, memproses, menyimpan hingga menganalisa informasi dan kemudian disebarkan untuk tujuan yang spesifik.
\end{abstract}

Manajemen sistem informasi berguna sebagai acuan untuk pengambilan keputusan dalam sebuah organisasi atau perusahaan. Lebih dalam tentang manajemen sistem informasi, tujuan, fungsi dan contoh penerapannya dalam bisnis 
FAKULTAS ILMU KOMPUTER

YULI YANAH

TUGAS 1 - SISTEM INFORMASI MANAJEMEN

1. MANFAAT SISTEM INFORMASI

Beberapa manfaat atau fungsi sistem informasi antara lain adalah sebagai berikut:

1. Meningkatkan aksesibilitas data yang tersaji secara tepat waktu dan akurat bagi para pemakai, tanpa mengharuskan adanya prantara sistem informasi.

2. Menjamin tersedianya kualitas dan keterampilan dalam memanfaatkan sistem informasi secara kritis.

3. Mengembangkan proses perencanaan yang efektif.

4. Mengidentifikasi kebutuhan-kebutuhan akan keterampilan pendukung sistem informasi.

5. Menetapkan investasi yang akan diarahkan pada sistem informasi.

6. Mengantisipasi dan memahami konsekuensi-konsekuensi ekonomis dari sistem informasi dan teknologi baru.

7. Meningkatkan efisiensi dan efektivitas data secara akurat dan realtime.

8. Memudahkan pihak manajemen untuk melakukan perencanaan, pengawasan, pengarahan, dan pendelegasian kerja kepada semua departemen yang memiliki hubungan atau koordinasi.

9. Meningkatkan kualitas sumber daya manusia, karena unit sistem kerja yang terkoordinasi dan sistematis.

10. Meningkatkan produktivitas dan penghematan biaya dalam organisasi 


\section{PENGARUH SISTEM INFORMASI MANAJEMEN DALAM PERUSAHAAN}

banyak perusahan-perusahaan yang menginvestasikan sistem informasi untuk meningkatkan produktivitasnya. terkadang sebuah perusahaan mengontrak seorang ahli IT ataupun mengirimkan staff karyawannya untuk mengikuti pelatihan mengenai upgrade sistem informasi. hal ini bertujuan supaya perusahaan tersebut tetap bisa menjaga stabilitas perusahaannya ataupun dapat bersaing dengan perusahaan lain. Berikut tiga peran sistem informasi manajemen dalam perusahaan:

1. Sistem informasi untuk operasi bisnis

Sistem informasi menyediakan dukungan manajemen dalam operasi kegiatan bisnis seharihari. Ketika tanggapan atau respon yang cepat menjadi penting, maka kemampuan sistem informasi untuk dapat mengumpulkan dan mengintegrasikan informasi ke berbagai fungsi bisnis menjadi kritis atau penting.

2. Sistem informasi untuk pengambilan keputusan manajemen

Sistem iformasi akan membantu para manajer membuat keputusan yang lebih baik, lebih tepat, dan lebih bermakna. setiap perusahaan tidak akan lepas dari yang namanya masalah, terutama dengan pengelolaan manajemen. melakukan pemecahan masalah merupakan aktivitas penting yang harus dilakukan oleh seorang manajer.

3. Sistem informasi untuk keunggulan strategis

Sistem informasi yang dirancang untuk dapat mencapai sasaran strategis dapat menyebabkan perusahaan menciptakan keuggulan bersaing di pasar. 
FAKULTAS ILMU KOMPUTER

YULI YANAH

TUGAS 1 - SISTEM INFORMASI MANAJEMEN

\section{PENGERTIAN DATA DAN INFORMASI}

A. Data merupakan bentuk yang belum dapat memberikan manfaat yang besar bagi penerimanya, sehingga perlu suatu model yang nantinya akan dikelompokkan dan diproses untuk menghasilkan informasi.

a. Data adalah nilai yang mendeskripsikan dari suatu objek atau kejadian.

b. Data adalah sesuatu yang belum mempunyai arti bagi penerimanya dan masih memerlukan adanya suatu pengolahan.

c. Data adalah bagian paling dasar/kecil dari karya manusia.

B. Informasi adalah hasil dari pengolahan data dalam bentuk yang lebih berguna dan lebih berarti bagi penerimanya yang menggambarkan suatu kejadian-kejadian sehingga akan berguna untuk pengambilan keputusan.

a. Informasi adalah sebagai data yang sudah diolah, dibentuk, atau dimanipulasi sesuai dengan keperluan tertentu

b. Informasi merupakan hasil pengolahan dari sebuah model, formasi, organisasi, ataupun suatu perubahan bentuk dari data yang memiliki nilai tertentu, dan bisa digunakan untuk menambah pengetahuan bagi yang menerimanya.

c. Informasi adalah data yang disimpan, diproses, atau ditransmisikan. 
FAKULTAS ILMU KOMPUTER

YULI YANAH

TUGAS 1 - SISTEM INFORMASI MANAJEMEN

\section{PROFESI SISTEM INFORMASI}

a. Webmaster

Profesi yang merupakan gabungan antara web designer and web programmer, webmaster bertugas untuk memelihara aplikasi web yang digunakan.

a. System Analis

adalah seseorang yang bertanggung jawab atas penelitian, perencanaan, pengkoordinasian, dan merekomendasikan pemilihan perangkat lunak dan sistem yang paling sesuai dengan kebutuhan organisasi bisnis atau perusahaan

b. Auditor Sistem Informasi

Adalah proes pengumpulan dan penilaian bukti - bukti untuk menentukan apakah sistem komputer dapat mengamankan aset, memelihara integritas data, dapat mendorong pencapaian tujuan organisasi secara efektif dan menggunakan sumberdaya secara efisien

c. Web Developer

adalah seseorang yang menciptakan aplikasi berbasis web dengan menggunakan bahasa pemrograman

d. Web Designer

adalah seseorang yang bekerja dengan unsur-unsur visual pada suatu halaman web

e. Database Administrator

adalah profesi yang bertanggung jawab dalam pengelolaan database yang dimiliki oleh organisasi, mulai dari pada saat proses implementasi database, monitoring kinerja database sampai dengan proses backup dan recovery apabila system mengalami gangguan

f. Database Analyst

adalah profesi yang bertanggung jawab dalam melakukan perancangan database.

\section{Kesimpulan}

System informasi manajemen mempunyai peranan yang sangat penting bagi perusahaan atau organisasi dalam pengambilan keputusan selain itu dengan adanya system informasi manajemen menjadi lebih efiien dan efektivitas. 
TUGAS 1 - SISTEM INFORMASI MANAJEMEN

\section{Daftar Pustaka}

Awan. Manfaat Sistem Informasi, http://islamiclivequotes.weebly.com/home/september12th-2015, Diambil April 112019 pukul 15.00

http://pangeranarti.blogspot.com/2014/11/pengertian-data-dan-informasi-lengkap.html

http://alfiqrirzb.blogspot.com/ 